\title{
Research of the Surplus in Sino-US Trade based on Comparative Advantage
}

\author{
YU Mengchen ${ }^{1, \text { a }}$ \\ ${ }^{1}$ Jiangxi college of foreign study, NanChang 330099, China \\ a yumengchen2016@126.com
}

Keywords: Trade surplus; Domestic demand; Export control; Foreign investment

\begin{abstract}
In Sino-US trade, Chinese exports to the United States is in rapid growth is entirely due to China's labor comparative advantage. Growth of Sino-US trade surplus is related to the influx of foreign capital into China, China's domestic consumer insufficient and the related technology products export control on China. In order to fundamentally solve the problem of Sino-US trade surplus, joint efforts of both sides of China and the United States is required.
\end{abstract}

\section{The comparative advantage theory}

\section{Absolute comparative advantage theory}

In his representative work The Wealth of Nations published in 1776, Adam Smith first proposed the absolute comparative advantage theory. In the book, Smith analyzed the benefits of free trade in detail and advocated free trade. Every country trades according to the absolute comparative advantage theory. As long as countries export its absolute production cost is lower than other countries' products in the international market, the welfare of the two countries have been increased. If foreign can give us manufacture goods more cheap than our own, we had better use we have the advantage industry, produce goods to buy these goods. The advantage of a country can have two sources: one is the natural advantages and the other is later advantage. [1]Smith thought that every country has its absolute advantage suitable for the production of certain products; the specialized production of its products at lower production costs and exchange products is good to participate in the exchange of all nations.

\section{Relative comparative advantage theory}

Adam Smith's theory of absolute cost has opened up the international trade theory research, which is also the beginning of the theory of comparative advantage. Smith thought all countries exchange commodity with absolute low cost can increase the production of products and consumption quantity will increase, so both sides get interests. But it makes the absolute inferiority in all products production country unable to participate in international trade. David Ricardo broke through the limitations of Smith's absolute advantage theory and put forward his relative comparative advantage theory. He illustrated through the establishment of a simplified model that even if a country has no absolute advantage, it still can benefit through comparative advantages in international trade. In this classic models, including the following assumptions: a kind of elements, two kinds of goods, constant return to scale, constant Labor productivity, relative labor productivity are different between the two countries. [2]By the model, the allocation of resources guided by price system under the condition of free trade, its different the ratio of the product cost comparing with the state department of product cost ratio, as long as the cost difference, the ratio of between different countries can also inevitably to carry on the exchange so as to get economic interests. Ricardo's comparative advantage says that comparative advantage is produced in labor productivity difference between countries, and this results labor cost difference.

\section{Research on the effects of the RMB exchange rate on China's trade surplus}

\section{Calculation of the real exchange rate}

Research on the calculation of the real exchange rate system is rare and lack of system theory. According to the research literature on exchange rate, the definition of the real exchange rate is 
divided into two kinds.

First, in order to reach the goal of increasing exports and restrict imports, governments often have fiscal subsidies or tax cuts for all kinds of export commodities to increase imports of various types of surcharge. At that time, the real exchange rate is the nominal exchange rate and the subsidy rate and is the sum or very short.

Formula is expressed as: Real exchange rate $=$ Nominal exchange rate + rate of export subsidies or tax cuts

Second, without considering the financial subsidies and tax breaks and inflation, the real exchange rate is the results after the nominal rate adjustment for inflation rate. If $E$ is nominal exchange rate that use of direct quotation. $P^{E}$ and $P$ are respectively on behalf of foreign and domestic price level, so the relationship between the real exchange rate and the nominal exchange rate is $R E E R=E * P^{E} / P$.

\section{Theoretical framework based on the model of the two countries}

First of all, this part studies the relationship between the trade balance and the RMB exchange rate. Marshall-Lerner elasticity theory and Keynesian national income theory on the theoretical framework to study the problem decide the model of the balance of payments. Due to the elastic theory assumes that a country's exports and imports are equal, which contract with the trade surplus from this article to study, so elastic theory model cannot be completely be used in this article. And international balance model is the relationship between the national income and the import and export trade difference. With the purpose of this study, therefore, this article will apply Keynes's theory of comparative static analysis of the balance of payments as the empirical analysis of the model framework. The derivation process of the model are as follows:

The model assumptions:

A. Trade balance involves only two countries, China and the United States.

B. Products Chinese exports to the United States and the products United States imported from China have certain difference, namely cannot entirely replace products made in domestic country.

C. Commodity market is monopolistic competition

Import demand of China and the United States depends on the country's total income level and the relative prices, namely:

$$
\begin{aligned}
& D_{M}^{C}=D_{M}^{C}\left(Y^{C}, e P^{X}{ }_{A} / P_{C}\right) \\
& D_{M}^{A}=D_{M}^{A}\left(Y^{A}, P^{X}{ }_{C} / e P_{A}\right)
\end{aligned}
$$

Because the commodity market is monopolistic competition, we assume that the supply of real exports and export only related to price :

$S_{X}{ }^{C}=S_{X}{ }^{C}\left(P^{X}{ }_{C} / e P_{A}\right)$

$S_{X}{ }^{A}=S_{X}{ }^{A}\left(e P^{X}{ }_{A} / P_{C}\right)$

$S_{X}{ }^{C}$ and $S_{X}{ }^{A}$ representing China and the United States export supply, when the market reaches equilibrium between the two countries, then:

$$
\begin{aligned}
& D_{M}{ }^{C}=S_{X}{ }^{C} \\
& D_{M}{ }^{A}=S_{X}{ }^{A}
\end{aligned}
$$

\section{Model set}

According to the theoretical derivation and the paper in front of the needs of the empirical analysis, take China's import and export to the United States equation and trade balance equation set as follows:

$$
\begin{aligned}
& \operatorname{LnEX}=\alpha_{O}+\alpha_{1} \operatorname{Ln} Y^{A}+\alpha_{2} \operatorname{LnREER}+\mu \\
& \operatorname{LnIM}=\beta_{O}+\beta_{1} \operatorname{Ln} Y^{C}+\beta_{2} \operatorname{LnREER}+\mu \\
& \operatorname{LnBA}=\theta_{0}+\theta_{1} \operatorname{Ln} Y^{A}+\theta_{2} \operatorname{Ln} Y+\theta_{3} \operatorname{LnREER}+\mu
\end{aligned}
$$




\section{The causes of Sino-US trade imbalance}

\section{Resources comparative advantage of China and the United States}

In bilateral trade, the comparative advantages of resources in China and the United States are very different. As the world's largest developing country, China has much skilled labor, land and other basic resources more abundant; it has huge potential consumer market but the development and utilization level is not high, therefore, China occupy a comparative advantage in labor-intensive industries. As the world's most developed capitalist countries, [3]The United States has abundant capital, research and strong technical strength, developed capital markets and financial system, and occupy obvious comparative advantage in technology intensive industries and service industries. Resource comparative advantage decided to international division of labor, the different international division of Labor decides the structure of bilateral trade. So, according to the comparative advantages in resources, in bilateral trade, China mainly exports labor-intensive products to the United States, the United States mainly exports to China of technology-intensive products and service.

\section{Macroeconomic imbalances between China and America}

The acceleration of global economic integration promotes the development of world economy, but, the international division of labor resulting from the economic globalization objectively has led to the world economic imbalances. In the world economic system, under the high speed of science and technology progress and the driver update, the western developed countries constantly optimize and upgrade industrial structure; the financial system is increasingly perfect and committed to realize the transformation of information economy to knowledge economy. For developing countries, due to the unreasonable industrial structure, lack of funds and related technology for a long time, underdeveloped financial market, all these lead to the development of social economy in a long term at a lower level. As the world's normal economic operation mode, economic imbalances is one of the basic law of the world economy, which have different performance at different times. When the imbalance came to extremely severe degree, the world economic imbalances will be released in the form of the economic crisis.

\section{International industrial transfer}

Economic globalization leads to the international division of labor and standardization production, which will lead to the international industrial transfer. After entering the 21st century, the international investment and the factors of production further speed up on a global scale, the mass flow of Europe and the United States, and other advanced economies transfer the related capital and technology intensive industries to China, even include the transfer of processing operations, even high and new technology international market competition factors so as to achieve the international investment and business in Chinese market. For reasons of resource and labor cost, Asia's emerging industrial countries and regions mass transfer the manufacturing to China, leading to the rapid development of China's manufacturing industry. At the same time, China's relevant labor-intensive industries are beginning to transfer slowly. [4]The diversification of international industrial transfer has characteristics of industry presents the diversification, which lead to international industrial transfer whole structure become increasing high.

\section{Suggestions to tackle with Sino-US trade imbalance}

Sino-US trade imbalance is the normal phenomenon in the process of bilateral economic and trade exchanges, which problems cannot be solved shortly. In advancing the process of Sino-US economic and trade cooperation, both sides should focus on long-term interests instead of dwelling in the bondage of temporary interest.

Take proper trade strategy to solve the dispute over the trade imbalances in the negotiations

Correct trade strategy can make us dominate when dealing with trade disputes so as to occupy a favorable position in solving trade disputes. In face the dispute, we have the following actions to take. 
Firstly, strengthen the dialogue communication with the United States to avoid politicizing trade issues. Fundamentally, the economic ties between China and the United States are good for both countries. Politicizing trade issues can only deepen the misunderstanding and friction, thus affecting the economic development of the two countries. Therefore, the long-term interests should be bear in mind in dealing with bilateral trade so as to avoid politicizing trade imbalances.

Secondly, attach great importance to the role of interest groups in the United States in the processing of trade issues. In the open and pluralistic political structures in the United States, interest groups in the United States government trade decision play an important role, someone called interest group as "the fourth part of the US government". So it is necessary to win support for China-friendly interest groups.

Finally is to master strategy for trade imbalance problem in the negotiations. If not only take goods trade policy as a bargaining chip and the United States in the process of negotiation, but also takes the service trade and investment related to multinational companies in the United States interests together as part of the strategic trade policy, then in practice could get more benefit. When conflict is inevitable, show its position clear. Clear attitude is able to make the trade co-operation in the next negotiation. The guiding ideology of our strategic trade should be clear attitude, strive for cooperation, avoid conflict, but take decisive measures accordingly when in conflict.

\section{Expand domestic demand to increase imports}

To resolve international payments imbalances should start from domestic balance. If the problem in total structure problems of the domestic economy cannot be solved, it is impossible to balance international payments.

In the overall pattern of global economic imbalances, our country belongs to the part that savings over investment, foreign trade surplus for a long time, its foreign exchange reserves keep expanding. Is the case, since the early $1990 \mathrm{~s}$, if the cause of the economic imbalances from investing side in China, it should also be attributed to the domestic investment rate not high enough, that cannot fully absorb national savings gradually increase. Due to the savings over investment situation stays for a long time, increase demand become necessary for long-term economic growth in China. In a long period of time, maintain a certain level of investment is still the policy priorities we must seriously consider, and, when necessary, to stimulate investment is likely to be a long-term policy.

\section{Adjust the industrial structure and export commodity structure in the direction of diversified foreign trade}

For a long time, our country keeps developing the export of labor-intensive enterprises, which has led to the structural disadvantages in the aspect of export products in our country at present, namely rely too much on the export of labor-intensive products. Excessively depend on the price competitiveness of the export model make China overly dependent on cheap labor in our country, so as to sacrifice the domestic labor welfare, deteriorate domestic income distribution pattern, and curb domestic demand growth. High-tech products increasingly become the main type of international trade, so China's competitiveness of labor-intensive products will gradually decline in the international market.

\section{Summary}

In the trade between China and the United States, despite the trade scale is big; it still follows China's comparative advantage of labor trade. The cause of forming and expanding of the China's trade surplus is comparative advantages of both sides, U.S. export controls and other policies limit its play of the comparative advantages of capital and technology; the influx of foreign capital in China and irrational structure, insufficient consumer demand factors promoted in the foreign trade export, the role of the two results is the expansion of China's trade surplus. To solve the Sino-US trade surplus, the two countries need to cooperate with each other. China should adjust the industrial structure as soon as possible to develop the service industry to promote employment and residents' income, at the same time, reasonable planning and utilization of foreign capital must be conducted. The United States should let go of the export control as soon as possible to avoid interference free 
trade policy.

\section{References}

[1] Chen Huajie, Guoyan. China's foreign trade dependency analysis [J]. Journal of international trade. 2008 (2): 242- 243.

[2] Maqiang. Analysis of China's foreign exchange savings from the standpoint of goods trade surplus [J]. China's economic and trade Tribune. 2006 (23): 42- 44.

[3] Shen Guobing. The United States export control and the Sino-US trade balance issue. World economics and politics [J], 2006.

[4] Chen Xuebin, Xu Mingdong. Quantitative analysis on the impact of the global financial crisis on China's foreign trade[J]. Fudan journal (social science edition). 2010(1). 